\title{
AN ANALYSIS OF SPEECH ACT IN THE GROWN UPS MOVIE
}

\author{
Lida Marbun, Nurma Dhona Handayani \\ marbunlida3@gmail.co,nurmadhona@gmail.com \\ Student of English Department, Lecturer of English Department \\ Putera Batam University
}

\begin{abstract}
This research discussed about the analysis of speech act used in the Grown Ups movie. This research revealed the types of speech act that found in the Grown Ups during the movie. The researcher applied the qualitative descriptive method because it was dealt with the description analysis by using words. Observation method used to collect the data. The researcher chose this movie because it was popular in the 20's century and there were many speech acts reflected in this movie. As the result, it was found that were 30 utterances of speech acts in Grown Ups movie. From the 30 data that researcher collected, the main characters most expressed the types of speech act. They are 6 locutionary acts, 15 illocutionary acts, and 9 perlocutionary. Based all the data above, it can be concluded the most used speech act found in this data was illocutionary act. The next was perlocutionary act. Then the last was locutionary act.
\end{abstract}

Keywords: Pragmatics, Speech act, Types of Speech Act

\section{INTRODUCTION}

Language is an interaction of living things equipment or an equipment of human in communication. In every communication humans convey information that can be thoughts, ideas, intentions, feelings, and emotions directly. Language always appears in the form of individual actions or speech acts. Therefore every study of language structure must start from the assessment of speech acts.
Speech acts are concrete manifestations of language functions, which are the basis of pragmatic analysis.

Speech acts are individual symptoms that are psychological in nature and continuity is determined by the speaker's ability to deal with certain situations. In speech acts, it is more seen in the meaning or meaning of the actions in the speech. The sentence "It's so hot in here!" This sentence can has various meanings in different situations. 
It means that the speaker only states the fact of the air condition at that time, asking someone else to open the window or turn on the air conditioner or even complaints. Therefore, understanding of speech acts are very necessary in communicating because people often be faced with the need to understand and use various types of speech acts, each of which can be realized through various strategies.

Speech acts is the theory that analyzes the effect of an utterance in the relationship between the speaker and the listener's behavior. There are three kinds of speech acts according to J.L Austin; locutionary acts, illocutionary acts, and perlocutionary acts. For short, in uttering a sentence, a speaker produces a locutionary acts or the saying; his cat in producing the utterance called illocutionary acts, and the effect of his saying toward the hearer called perlocutionary acts.

These are the simple understanding of the difference of speech acts Austin (1962).In other words Speech acts is essential to efficient communication as it allows individuals to conduct a broad variety of tasks such as affirming, stating, blaming, concluding, explaining, informing, notifying, praising and others. Speech acts can happen anywhere, in the movie, in the novel, or in the learning or teaching process.

The different types of speech act reveal many functions such as gives information about fact, educated information, manner, flattery and intercommunicate Searle (1969).
Speech acts are really important. Representative acts are one of the short of speech acts that was essential in the teaching and learning process. Representatives are the types of speech acts that state what the speaker thinks is the case or not. For instance: to state, to suggest, to boast, and to complain, to claim and to report.

There is some analysis for speech act in previous study. The first is by Altiriti (2011), the researcher focus on findings that the using of speech acts fluctuated both in quantity and type from one writer to another and from one theme to another in three short stories. The next analysis is by Tutuarima, Nuraeningsih \& Rusiana (2018), the aims of the research are to find out the kinds of speech act used in London Has Fallen Movie and to find out the way of speech act and the classifications of illocutionary act used in London Has Fallen Movie. This research uses descriptive qualitative research. This research figures out the kinds of speech act and the classifications of the illocutionary act used in London Has Fallen Movie. Based on the previous study the researcher will conduct an analysis in a movie by Dennis Dugan "Grown Ups".

The type of speech act can be an issue for analyzing a speech act in the movie. Many researcher conduct the same issue in analyzing speech act. The researcher has found speech acts in the "Grown Ups" movie. Then the researcher analyze the type of the speech act, either it is locutionary, illocutionary, or perlocutionary. This 
research leads us to know more about the speech act and the movie itself.

Based on background and the problem or issue that researcher explains above. The researcher attracted to conduct the speech act analysis especially in the movie "Grow Ups". The researcher also feels it is important to conduct this researcher. It is a Consideration the lack of people who understand the speech act.

\section{Speech Act}

Speech acts is one branch of pragmatic as branch of linguistic study that discuss about the act of asking others through an utterance. It means that the speaker asks the hearer to do something by what he or she said. So the speaker must see the hearer that he headed. The hearer must have same background knowledge with the speaker so get the intention. The same background knowledge means that the people who understand intended meaning.

Speech acts have become important thing in the of linguistics subject. There are several experts who given a different understanding of speech acts. The meaning of speech act was began by Austin (1962) and expanded by Searle (1969). According to Austin "speech act is an act performed when someone says something". According to him there are three types of speech acts such as locutionary act, illocutionary act, and perlocutionary act.

Austin (1962) added that speech acts are the actions that done via language. Speech acts are the objects that people do through language for example apologizing, complaining, instructing, agreeing, and warning. The five examples above are the action of speech act. The next Yule (2010) said that actions performed via spoken word is speech acts. The researcher concludes that speech act is one part of pragmatics that discusses how the speaker gets something from the hearer with asking via utterances.

\section{Austin's Categorization of Speech Acts}

Austin (1962) declared three types of speech acts differently. They are locutionary act, illocutionary act, and perlocutionary act. The first locutionary act is deliver an utterance contents sense and reference that suited the simple meaning of sense by Austin (1962). The simply meaning of sense is locutionary acts shown the acts of speaking something. In addition, Leech (1989)created a rule of this act: $\mathbf{M}$ tells to $\mathbf{G}$ that $\mathbf{Y}$. The rule has meaning that $\mathbf{M}$ is a speaker, $\mathbf{G}$ is the hearer, and $\mathbf{Y}$ is certain sense and reference.

Searle divides it into two, namely: Utterance act, i.e. words. This speech act includes two locus speech acts from Austin.

Prepositional actions i.e. refer and predict. This action is the third act of locution to Austin. This kind of speech act then revealed illocutionary acts and perlocutionary acts.

The second type of speech acts is illocutionary acts. According to Austin (1962), illocutionary acts is an spoken word that has certain power. It has same meaning with the action that people do 
when said something. This act can pictures as: when speak a word the speaker explained the proposition related to Leech (1989) utterance. The researcher found George Yule (2010) gives an example "I've just made some coffee". This example has meaning the speaker wants the hearer know that she or he makes some coffee or it also as a statement.

Austin divides illocutionary acts into five sub-types: The first is Verdictives, speech acts that are marked by rightwrong decisions, for example (note the underlined word). "Hamdan is accused of being the mastermind behind the demonstration". The second is Exercitives speech act that are the result of power, rights, or influence, for example "I ask you to come to the office early in the morning," Zacky told his secretary; The third is Commissives speech acts that are marked by agreements or actions that cause the speaker to do something, for example "National University signs cooperation with University of Malaya in publishing scientific journals," Lina said in front of a leadership meeting.

The next is Behavitives speech acts that reflect social concern or sympathy, for example "The Singaporean government is concerned about Indonesian migrant workers who experience torture in Saudi Arabia", and the last is Expositives speech acts used in simplifying the definition, for example "bail out" is like someone whose debt to someone is paid by someone they don't know. "The last type of speech act is perlocutionary acts. This act denotes the utterances result. It has same meaning with notify what speakers want obtain in saying something such as to get hearers to know, to do something, to expect something, to show speaker's feeling and to praise Austin (1962).

Based on explanation above, he makes an example of this act: when someone yells "Fire!" then it makes people to exit a room which is on fire, they have performed the perlocutionary act of getting hearers to exit the room. Whereas Leech (1989) stated that the formula of perlocutionary act is by saying $\mathrm{X}, \mathrm{s}$ convinces $\mathrm{h}$ that $\mathrm{P}$ e.g. by saying "I've just made some coffee", the speakers performs the act of causing the hearers to account for nice smell or to get the hearers to drink some coffee. In summary, the speaker utterances may not be meaningless but their utterances can give effects to the hearers in the form of the hearer's reaction to the speaker's utterances.

\section{Felicity Condition}

Felicity condition is the situation where the speaker has the authority to pronounce something. For example a doctor pronounced him as tuberculosis person. Related to example above, the speaker that has authority is a doctor. It is because the doctor has authority pronounce a disease. In daily life we can see the simple example when your friend pronounced You as cancer disease, You can angry and didn't believe him.

According to Cutting (2002) stated that the felicity conditions are the good speaker motif and the action must do correctly. Searle in Cutting (2002) 
put together that there is a certain condition which the speaker must honest and the hearer must understand the intention. Based explanation above has meaning the people that want to talks something started well, and the people who hear the utterances known the speaker aim. The hearer must be listening carefully.

Yule (2010) classified five preconditions on speech acts among ordinary people in daily context. The first pre-conditions deal with the general condition of the participants. It means that the audience must know the language be using and say truthfully. The second pre-condition is the future situation. The future situation is the condition that still waiting. For example is a promise.

The third pre-condition is preparatory condition, for instance when someone promises to do something, there are two preparatory conditions namely the events not happen by itself and have a beneficial effect. The next pre-condition is seriousness situation which the speaker said a promise and fulfill it. The last condition is certain situation which the speaker saying something intended for someone.

\section{RESEARCH METHOD}

Methodology of the research presents the research method, design, and procedures to answer its research questions. The discussion includes the research design, research subjects, research instrument, data collection procedures, and techniques of data analysis.

\section{Research Design}

This research uses the qualitativedescriptive method. To explore and understand the meanings of various individuals or groups of people deemed to derive from social or humanitarian problems. So, this research used a qualitative approach to analyze this topic about speech act.

The researcher used observation method by Sudaryanto (1993) in collecting data process. He stated that observation method is a technique to get information about human behavior by watched and recorded without any direct contact. The data were collected from the movie. There are some procedures which the researcher done in collecting the data. (1)The first, the researcher watched the Grown Ups movie. (2) Second, finding the which words that contains of speech act (3) Third, classifying which utterance that the researcher wanted to find that is contained with the type of speech act.

\section{Method of Analyzing Data}

In analyzing the data, the researcher applied theory from Austin's theory. The theory is applied by using method of Sudaryanto (1993) by using Pragmatics Identity Method. Data Analysis Procedures

In data analysis, the researcher analyzes the data through several steps below: 
a. The researcher classifies the types of speech act that is found in the Grown Ups movie.

b. Finally, the researcher interprets the meanings and explanation based on the theory that is used.

\section{Method of Presenting Data}

After doing analysis, the next step is presenting the result analysis. The researcher used informal method which informal method refers to the process of presenting the outcome analysis with words: it means that the results can be represented using words or phrases. The result analysis is also provided through the use of informal approach for presenting the data analysis. The result was presented by using words and sentences and to make the readers easily understand.

\section{FINDINGS AND DISCUSSION}

\section{Findings}

\section{Illucotionary Act}

\section{Data 1:}

Coach: Now, I want you to promise me something. I want you to play life just like you played that game today. So when that final buzzer of life goes off you'll have no regrets.

All participant: Yes coach.

This sentence is the act of illocutionary, because in the second the coach said this sentence, they accepted it and return it with drink together. The intention of the coach for saying this sentence is to make his team can be strong and happy with their life. This sentence is directive act that has a force for requesting. The coach requests the team to be more enthusiasm for his life.

\section{Data 2:}

Greg: Dude, you gotta text her. She's doing laundry.

This sentence is the act of illocutionary. Because after Greg said this declarative sentence there is a perform act by Keith. The context is after Lenny mention a game and his history for playing the game ladder and snake in the basement while drinking hot chocolate. Keith suddenly wants the hot chocolate to then he yell at his babysitter to get it for him. This illocutionary acts is the kinds of directives that has a force of suggesting.

\section{Data 3:}

Lenny: What is the object here? I don't get it. You're on a cruise ship and you chop people's heads off with a chain saw?

This sentence is the act of illocutionary. Because after Leni said this interrogative sentence, there is perform act by Keith. The context is when Leni still confusing about his kids playing game in the PlayStation 3. He wants an explanation from them about the game so he said that sentence. This illocutionary acts is the kinds of assertives that has a force for ensuring.

\section{Data 4:}

Greg : Why You texted everybody?

Lenny : I text people for my job so I can make money to pay your texting.

The Greg's utterance is the act of illocutionary. Because after Greg said 
this declarative sentence, there is a perform act by Lenny. The context is when Greg felt thirsty and wanted some tea. He wanted to text the babysitter to bring him the tea, but Lenny argues that it is not polite for the babysitter to get text for an errand inside the house. Also this illocutionary act is the kinds of assertives that has a force for arguing.

\section{Data 5:}

Andre: Deanne, do you hear how they talk to me? Do you hear how...? You gotta say something.

Deanne: I cannot hear it.

Andre's utterance is the act of illocutionary. Because after Andre said this declarative utterance, there is a perform act by his wife (Deanne). The context is after he cooked his family dinner their kids didn't like the food that he cooked. Then the kids start giving bad opinion about his food. So he wants his wife to say something to them. Also this illocutionary act is the kinds of directive that has a force for commanding.

\section{Data 6:}

Lenny : Is that your bra, Mrs.

Feder?

Deanne : Easy.

This sentence is the act of illocutionary. Because Lenny said this interrogative sentence, there is performing act by Lenny. The context is when Lenny still confusing about about the location of Feder's bra. He wanted an explanation from them about the bra so he said that sentence. This illocutionary acts is the kinds of assertives that has a force for ensuring.

\section{Data 7:}

Lenny: I want you to stop making up lies about kicking my ass or I'm gonna have to set you straight.

Becky: Sure, sure, sure. You be having to great summer.

Lenny's utterance is the act of illocutionary, because Lenny said this sentence, he wanted to stop lies. The intention of the coach for saying this sentence is to make his team can be strong and happy with their life. This sentence is directive act that has a force for requesting. The coach requests the team to be more enthusiasm for his life.

\section{Data 8:}

Deanne: I trust you, and I want you to have fun tonight.

This utterance is the act of illocutionary, because Deanne said this sentence, she trusted. The intention of Deanne saying that she trusted her husband and she wanted her husband to have fun tonight. This sentence is directive act that has a force for requesting to his husband.

\section{Data 9:}

Deanne: And that was his response. Does it bother you that I still wear it?

This sentence is the act of illocutionary. Because Deanne said this interrogative sentence, there is performing act by Deanne. The context is when Deanne still confusing about the respon of his husband if she bother her wearing the clothes. So she wanted his These illocutionary acts are the kinds of assertives that has a force for ensuring. 


\section{Data 10:}

Deanne : So, what do you think? Do I take you straight to work? I got one appointment I got to get to sometime between 8:00 a. $\mathrm{m}$.

Kurt: Okay.

This sentence is the act of illocutionary. This declarative utterance, there is a perform act by his husband. The context is when Deanne had appointment at 8.00 so she asked her husband to ask her opinion. So she wanted his husband to convince her to go or not. Also this illocutionary act is the kinds of directive that has a force for commanding

\section{Perlucotionary Act}

Data 1:

Leni: Here's to coach.

This sentence is the act of perlocutionary, because of the intention of the speaker (the coach) before. This sentence as the result of the intention itself in the context Leni said this sentence to respond the coach speech. He said this to salute his coach because of his guidance for basketball. The researcher feels that he and the team really admire their coach.

\section{Data 2:}

Keith: Oh, and you can drown them.

This sentence is the act of perlocutionary because of the intention of the speaker (Lenny) before. This is also the respond of the intention by the speaker. In the context after Lenny want to ensure that he explained the game clearly after he saw it. Keith responds with additional information for the game. The researcher feel that in this respond, Keith want his dad understand how good his game is.

\section{Data 3:}

Lenny: I text people for my job so I can make money to pay for your texting.

This sentence is the act of perlocutionary because of the intention of the speaker (Greg) before. This is also the respond of the intention by the speaker. In the context when he suggesting to his son that it is not polite to text baby sitter to do an errand. His son argued that he texted people to. The researcher feels that in this respond, Lenny want to educate his son how to be a polite person.

\section{Data 4:}

Deanne: All right, kids. Now, you know your father works very hard at keeping this house clean and putting meals on the table for us.

This sentence is the act of perlocutionary because of the intention of the speaker (Andre) before. This is also the respond of the intention by the speaker. In the context when her husband cooked a dinner for his family but the meal is bad and the family start give some bad opinion. So her husband wants her to give some talk to them. The researcher feel in this respond, Deanne want to tell her family how hard her husband work in the house.

\section{Lucotionary Act}

Data 1:

Lenny: I am the biggest agent in Hollywood and you just pissed me off.

This sentence is the act of locutionary. Because in this declarative 
sentence there is none perform action on the respond. This act also called constative, in the context Lenny was in the phone for his job. His job is to be an agent for finding the good actor for the movie.

\section{Discussion}

After analyzing the data, the researcher found some findings. There are three types of speech act. From the 30 data that researcher collected there are 6 locutionary, 15 illocutionary acts, and 9 perlocutionary. If we look all the data above, the most used speech act found in this data is illocutionary act. The next is perlocutionary act. And the last is locutionary act. Due to this research is not fully takes all population of the object. The researcher can't decide the dominant speech act found in this movie or object.

\section{CONCLUSION AND SUGGESTION}

\section{Conclusion}

From all the research analysis and finding above, it is important to know about the type of speech act itself. This research can classified the type of speech act in the Grown Ups movie. The finding reveals that the character played like to tell their speech act through the utterance. As a result of this research, it contains illocutionary, perlocutionary, and locutionary speech act. The reason also different based on the speech act that they used.

\section{Suggestion}

After all the data research was found and the conclusion was made, the research gives suggestion for the reader who reads this research. For the other researchers who is going to analyze this research should do this research with the direct source, it would be easier. For the reader who is student or ordinary people, they must consider their talk between each other because misunderstanding always happens, but the important is being polite and not saying words that could insult people is the point.

\section{REFERENCES}

Altikriti, S. F. (2011). Speech act analysis to short stories. Journal of Language Teaching and Research, 2(6). https://doi.org/10.4304/jltr.2.6.137 4-1384

Austin, J. L. (1962). How do to Things with Words. https://doi.org/10.1093/acprof:oso/ 9780198245537.001.0001

Cutting, J. (2002). Pragmatic and Discourse. (P. Stockwell, Ed.). London: Routledge.

Leech, G. (1989). Principles of Pragmatics Longman Linguistics Library.pdf.

Searle, J. R. (1969). Speech Acts: An Essay in the Philosophy of Language [Taschenbuch]. 
Sudaryanto. (1993). Method dan teknik analysis bahasa. Yogyakarta: Duta Wacana University Press.

Tutuarima, Z., Nuraeningsih, N., \& Rusiana, R. (2018). An Analysis of Speech Act Used in London Has Fallen Movie. Vision: Journal for Language and Foreign Language Learning, 7(2), 122.

https://doi.org/10.21580/vjv7i2302 2

Yule George. (2010). The Study of Language (Fourth). Cambridge University Press. Retrieved from www.cambridge.org/97805217652 75 